DOI 10.18551/rjoas.2019-03.33

\title{
PERFORMANCE OF MANGUNAN NATURE TOURISM, BANTUL OF INDONESIA
}

\author{
Kussujaniatun Sri ${ }^{\star}$, Harjanti Sri \\ Faculty of Business and Economics, University of National Development "Veteran" \\ Yogyakarta, Indonesia \\ Hanjani Asalia Noor \\ College of Management, Asia University, Taiwan \\ *E-mail: sri.kussujaniatun@upnyk.ac.id
}

\begin{abstract}
The development of tourism sector starts by identifying the tourism potential and need assessment. This research aims at describing the tourism performance, mapping tourism potential and identifying need assessment of the tourism objects in Mangunan village, Bantul, Yogyakarta. The data were obtained using survey method and questionnaire as well as Focus Group Discussion. The analysis conducted is descriptive statistics analysis. The research results show that there are 3 tourism villages and 10 tourism objects. The results of the need assessment show that most of the tourism objects need to improve the quality and the number of creative and innovative photo spots, empower the society for the photography business, build fruit stalls and organize the treatment systems for the fruits, train the customer service and conduct occupational health and safety training, motivate the young generations, improve housekeeping, innovate the culinary products, and conduct waste management.
\end{abstract}

\section{KEY WORDS}

Tourism potential, mapping, need assessment, public service.

Mangunan tourism is located in Dlingo district in Bantul, Indonesia. It is famous for its unique attractions such as pine trees, waterfall, cave, and breathtaking view from the top of the hill. The tourism development program is supported by the government by establishing Kelompok Sadar Wisata (Tourism Awareness Group) that cooperates with industries or private businesses to conduct and support the tourism development. The development of the sustainable tourism can be seen from the three significant aspects, which are environment, social, and economy aspects (Fennell, 2003; Baker, 2006; Mowforth\& Munt, 2007; Risteski et al., 2012; Sesotyaningsih \& Manaf, 2015).

Therefore, tourism development needs to pay attention to the position, potential, and the roles of the society both as subject or actor and as the ones taking the benefits from the development. The support from the society also determines the success of the tourism development. Society with high empowerment is the society that is physically and mentally healthy, educated and strong, and having intrinsic values that serve as the source of the empowerment, such as togetherness and cooperation (Zubaidi, 2013).

The unique and attractive tourism potential needs to have the right tourism development so that it can attract a large number of tourists. Therefore, there is a need to conduct tourism mapping for each region in Mangunan village since this village has numerous tourism potentials to offer. The goal of the tourism mapping is to clearly identify the types and the potentials of the nature tourisms whether they are in the developing or in the under-developed stages. The tourism mapping will determine the locations of the tourism spots so that the local and international tourists can choose the tourism spots that they want to visit. Besides, the development of the tourism potential will increase the income of the society. 
A research conducted by Kussujaniatun 2017 about Bojonegoro shows that there is a need to conduct tourism development of the teak crafts, batik, culture tourism, tourism village, and farm that serve as tourism attractions in Bojonegoro.

Furthermore, tourism mapping also provides excellent opportunities to increase foreign exchange, so that the research about tourism mapping in Mangunan village is necessary to conduct.

\section{MATERIALS AND METHODS OF RESEARCH}

According to Pendit (2003) tourism potentials are numerous resources in a certain area that can be developed as tourist attraction that eventually can improve the financial and other aspects.

Mariotti (Bayu, 2011) adds that tourism potential is the attractions so that people would like to come to visit the places. Besides, Sukardi in Bayu (2011) also argues that there is a need to develop the tourism industry. Based on Obioma (2013), the types of tourism potentials are:

- Nature tourism potential is everything related to beautiful nature such as cave, highland, mountain, waterfall, rocks, wild animals, water sources, and so on;

- Culture tourism potential is everything related to culture and the unique of the people, both artificial and heritage such as dance, music, tradition, historical monument, pictures, arts, crafts, festivals, weddings, and so on;

- Artificial tourism is based on the man-made technology and innovation in entertainment aspect (cinema, theater, museum, park), sports and recreation (swimming pool, sport clubs, social club), accommodation (hotel, guest house), restaurants, hotel and transportation facilities such as travel agent, tour operator and tourism information center, and so on.

The main techniques used in this research are observation, open in-depth interviews with the local community (Kussujaniatun, 2017), literature study and survey. Data gathering involves the community on the tourism activities, the benefits from the tourism village development (Sesotyaningsih \& Manaf 2015).

The data were obtained using questionnaires and Focus Group Discussion and analyzed using descriptive statistics analysis. The research results show that there are 3 tourism villages and 10 tourism objects. The mapping method as used by Vitasurya (2015) emphasizes the involvement from the target as active subjects, make use their experience as integral part in the research, identify the problem, and solve the problem with the target of empowerment of the research subjects.

\section{RESULTS OF STUDY}

The result is the tourism mapping. It is obtained by conducting data observation from the government and existing community, interviews with the tourism village managers, tourism awareness group, and observation on the right mapping needs.

Tourism sector development is one of the efforts to improve local income. There are various tourism objects in Mangunan with the mapping as follows.

The characteristics of tourism village are the original and pure resources, the unique of the village and its traditions and culture of the local community. Tourism village provides new alternative for the tourists not only to enjoy the beautiful view but also to learn and to introduce the village life of the community.

Bantul has 27 developed tourism villages, and 3 of them are in Mangunan, namely Tapak Tilas Sultan Agung (developing), Songgo Langit (developing), and Kaki Langit which most of its residents are wood craftsmen. There are various crafts that serve as souvenirs made of wood such as table, chairs, picture frames, and many more.

On weekend, the location around Mangunan Spring serves as Art Market of Kaki Langit. This market is attractive since we can find numerous village culinary items that are rarely found such as thiwul, gudeg manggar, kelanan, brongkos, wedang uwuh, and many 
more. All of the sellers in the market wear Java traditional costume. The unique thing is about the payment method. Before we enter the market we have to exchange our money to coins made of wood. The coins are then used as payment tools to shop in Art Market.

There are several homestays in Kaki Langit tourism village for the tourists if they would like to stay and spend more time to see the life of the society. These homestays are managed directly by the local people in the village. There are 8 activities that tourists can do in this village, namely Atap Langit, Langit Cerdas, Langit Ilalang, Langit Terjal, Langit Hijau, Budaya Langit, Karya Langit, and Rasa Langit.

All of the activities offer live in-based activities along with the homestays in which the tourists can get experience of living together with the host or the owner of the house, outbound, and get farming method education. Visitors can also enjoy the local food such as gathot and tiwul ayu and typical drink of Mangunan village. They can also visit wood crafts home-based industries and bamboo plaits, enjoy the traditional art performance of the village like gejlok lesung, kethoprak wayang, and many more.

Mangunan Pine Forest is one of the Forest Management Resorts in Mangunan. The open area with tall trees will become an interesting attraction for the tourists. The distance from the city of Yogyakarta is around $23 \mathrm{~km}$ and the forest can be reached for about 60 minutes by cars or motorcycles. The entrance ticket is Rp. 2500 and the parking fee is Rp.3000 for the motorcycles and Rp. 10.000 for cars. The facilities offered include viewpoints to enjoy the beautiful view, outbound areas, musholla, toilets, and parking lots.

This tourism object is one of the nature resorts with natural panorama with similar concept as in Pine Forest. This tourism object is an educational tourism with the concept of fairytale that offers numerous attractions such as hobbits photo spots, wood bridge that connect trees, viewpoints, treehouse, and many others. Besides, there is also Flying Fox area. The entrance ticket is Rp. 2000. The further development plan of the tourism is to build a theatre that serves as a spot for story telling or drama performance to spread kindness. It is expected that the visitors can get the moral message.

Panguk Kediwung Hill was opened for public in the middle of 2016 by the local people. Panguk Kediwung Hill offers the beauty of sunrise above the clouds. The best panorama in Panguk Kediwung Hill is the sunrise and mist that shapes like clouds. This situation makes the tourists feel like having sunrise in the land above the clouds. There are more than five photo spots, and visitors need to pay after taking pictures in some of the spots. The retribution for the tourism object is Rp.2000 for motorcycles and Rp. 5000 for cars. The facilities provided in this object are toilets, parking lots, and some places to eat.

Mojo Hill is located in Gumelem, Mangunan, Dlingo, Bantul. The interesting thing in Mojo Gumelem Hill is the photo spot of a huge bird nest above the hill. This becomes the most favorite spot for the tourists. There are 3 viewpoints around the tourism object of Mojo Hill that can be used as photo spots and to enjoy the beautiful views. The tourists can pay the entrance ticket and parking lot fee as they like.

The local people started to manage Watu Goyang tourism object in the middle of 2016. The main advantage of Watu Goyang is that we can enjoy the view around Imogiri. The top of the cemetery or the burial ground of the kings of Imogiri can be seen from Watu Goyang. The most interesting thing is of course the view of the sunset since the peak of Watu Goyang hill faces to the west. The entrance ticket is still free since there are still few facilities and the object is still new. However, the facilities are sufficient, such as gazebos, public toilets, musholla, places to eat, and some spacious parking lots.

Mangunan Fruit Garden is located in Mangunan village, Dlingo district, Bantul, Yogyakarta, $15 \mathrm{~km}$ from the Bantul city center and $35 \mathrm{~km}$ from Yogyakarta city center. Mangunan Fruit Garden is built on 23,3415 ha land with the height of $150 \mathrm{mdpl}-200 \mathrm{mdpl}$. Besides its breathtaking view and fresh air, Mangunan Fruit Garden is also called the land above the clouds. Tourists can enjoy various fruits arranged beautifully according to the slope of the land such as durian, mangosteen, dukuh, rose apple, oranges, mangos, rambutan, and many more. It also has complete facilities such as outbound area, flying fox, bridges, camp ground, accommodation area, meeting rooms, toilets, musholla, and so on. 
Watu Lawang is located on the west side of Mangunan Fruit Garden. Watu Lawang is very famous for its farm view that is located on Kedungmiri village and bridge in Imogiri. Watu Lawang's name is taken from Javanese word of Lawang which means door. This is due to the top of the hill that splits and looks like a door. For the parking fee, it takes Rp. 2000 for motorcycle and Rp. 5000 for cars.

The uniqueness of Gajah Cave in Mangunan is the entrance of the cave. The shape of the cave mouth is horizontal but the exit is vertical with a huge tree from underground reaching to the cave exit. Gajah cave is a horizontal cave with the depth of 200 meters. The cave is still natural with its stalactite and stalagmite along the cave. Gajah cave is still not managed seriously. Only local people who keep the cave well.

Tembelan Cliff is still a new tourism spot in Yogyakarta. Tourists usually come to take selfies and take sunrise or sunset pictures. Compared to Panguk Hill and Mojo Hill, Tembelan Cliff has more advantage in its viewpoint or Gardu Pandang with the shape of a vessel. It also has sufficient facilities such as some viewpoints, toilets, parking lots, and gazebos.

Table 1 - Tourism Objects Description

\begin{tabular}{|c|c|c|}
\hline No & Tourism Objects & Visitors \\
\hline 1 & Asri Pine Forest & 63,600 \\
\hline 2 & Mangunan Fruit Garden & 36,300 \\
\hline 3 & Seribu Batu Songgo Langit & 32,481 \\
\hline 4 & Panguk Hill & 7,082 \\
\hline 5 & Mojo Hill & 937 \\
\hline 6 & Gajah Cave & 347 \\
\hline 7 & Watu Goyang & 7,656 \\
\hline 8 & Watu Lawang & 2,481 \\
\hline 9 & Tembelan Cliff & 3,453 \\
\hline 10 & Mangunan Spring Kaki Langit & 80 \\
\hline
\end{tabular}

Table 2 - The Number of Visitors in Nature Tourism Objects in Mangunan Village

\begin{tabular}{|c|c|c|}
\hline No & Facilities & Number \\
\hline 1 & Home Stay & 673 (rooms) \\
\hline 2 & Jeep & 487 (trips) \\
\hline
\end{tabular}

Based on the data of the number of the visitors in Mangunan Village, it shows that there are several potentials such as Asri Pine Forest, Seribu Batu, Panguk Hill, Mojo Hill, Watu Goyang, Mangunan Fruit Garden, Watu Lawang, Gajah Cave, and Tembelan Cliff with their own potentials and attractions. Out of the 9 tourism objects In Mangunan Village, most of the visitors come to Asri Pine Forest with 190.800 visitors each month, while the lowest number of the visitors is in Gajah Cave with 1.041 visitors each month. The number of the visitors' arrival depends on the accessibility, facilities, and attractions of the tourism objects.

Generally, the problems faced in tourism development are (1) Lack of competent human resources. As a result, there is a lack of sense of belonging of the tourism object and there is a gap between the tourism manager and the actual actors in the field. (2) Insufficient infrastructure and facilities in numerous tourism objects. (4) Lack of promotion of some tourism objects so that the visitors do not know about their potentials and eventually the visitor only come to Pine Forest and Mangunan Fruit Garden. (4) Lack of government's realization to conduct tourism development so that the tourism is still in terms of plan. (5) Lack of involvement of the tourism industries such as travel agents, accommodation, and so on. The cooperation is needed since it is expected that it can improve the tourism so that the tourism can give more strength in this globalization era. The role of the tourism department is crucial related to the promotion of the tourism in Mangunan Village in Dlingo district to the tourism industries.

The result of the Focus Group Discussion with the head of head of the tourism village manager and its team shows some information related to things need to do in each tourism 
potential in Mangunan Village to increase the number of the visitors. The information is shown in the following table:

Table 3 - Industry Type Description

\begin{tabular}{|c|c|c|}
\hline No & Industry Type & Need Assessment \\
\hline \multirow{3}{*}{1} & \multirow{3}{*}{ Asri Pine Forest } & Add attractive and creative selfie spots \\
\hline & & Improve photo spots' quality to be more innovative and creative \\
\hline & & Empower the society to conduct photography business \\
\hline \multirow{2}{*}{2} & \multirow{2}{*}{ Seribu Batu } & Improve photo spots' quality to be more innovative and creative \\
\hline & & Empower the society to conduct photography business \\
\hline \multirow{3}{*}{3} & \multirow{3}{*}{ Panguk Hill } & Improve photo spots' quality to be more innovative and creative \\
\hline & & Empower the society to conduct photography business \\
\hline & & Improve photo spots' security \\
\hline \multirow{3}{*}{4} & \multirow{3}{*}{ Mangunan Fruit Garden } & Provide fruit stalls and souvenirs \\
\hline & & Empower the society to conduct photography business \\
\hline & & Organize fruit treatment system \\
\hline \multirow{3}{*}{5} & \multirow{3}{*}{ Watu Lawang } & Improve photo spots' quality to be more innovative and creative \\
\hline & & Empower the society to conduct photography business \\
\hline & & Improve photo spots' security \\
\hline \multirow{3}{*}{6} & \multirow{3}{*}{ Gajah Cave } & Add attractive and creative selfie spots \\
\hline & & Empower the society to conduct photography business \\
\hline & & Improve photo spots' security \\
\hline \multirow{4}{*}{7} & \multirow{4}{*}{ Tembelan Cliff } & Improve photo spots' security \\
\hline & & Add attractive and creative selfie spots \\
\hline & & Empower the society to conduct photography business \\
\hline & & Improve photo spots' security \\
\hline \multirow{3}{*}{8} & \multirow{3}{*}{ Mangunan Spring } & Improve photo spots' quality to be more innovative and creative \\
\hline & & Empower the society to conduct photography business \\
\hline & & Add attractive and creative selfie spots \\
\hline \multirow{4}{*}{9} & \multirow{4}{*}{ Mojo Hill } & Improve photo spots' quality to be more innovative and creative \\
\hline & & Add attractive and creative selfie spots \\
\hline & & Empower the society to conduct photography business \\
\hline & & Improve photo spots' security \\
\hline \multirow{3}{*}{10} & \multirow{3}{*}{ Watu Goyang } & Add attractive and creative selfie spots \\
\hline & & Empower the society to conduct photography business \\
\hline & & Improve photo spots' quality to be more innovative and creative \\
\hline \multirow{6}{*}{11} & \multirow{6}{*}{ Tourism Village } & Customer service training \\
\hline & & Motivation training for young generation \\
\hline & & Occupational Health and Safety training \\
\hline & & Housekeeping training \\
\hline & & Culinary product differentiation training \\
\hline & & Waste management training \\
\hline
\end{tabular}

\section{CONCLUSION}

There are 3 potentials for tourism development, namely Tapak Tilas Sultan Agung, Songgo Langit, and Kaki Langit. Kaki Langit is one of the famous tourism villages. The majority of the residents work as wood craftsmen. There are some homestays managed by the residents. This village offers 8 activities for the tourists. On Saturday and Sunday, there is Kaki Langit Art Market in around Mangunan Spring. It shows that Kaki Langit has numerous potentials.

There are 10 tourism objects offered by Mangunan Village such as Asri Pine Forest, Mangunan Fruit Garden, Seribu Batu Songgo Langit, Panguk Hill, Watu Lawang, Gajah Cave, Tembelan Cliff, Watu Goyang, Mojo Hill, Mangunan Spring with their own potentials and attractions. The total of the visitors in those objects reaches 463.251 visitors. Most of the visitors are in Asri Pine Forest of 190.800. Asri Pine Forest offers an open area with its tall trees and special selfie spots such as a small theatre, bridge, and hammocks.

Meanwhile, tourism object with the lowest number of visitors is in Mangunan Spring with 240 visitors. Even though Mangunan Spring has its own attractions like spring from Wali 
Songo time and Art Market, those objects still do not attract a large number of visitors. This is due to the poor facilities in the tourism objects.

Related to the potentials of the tourism villages and the tourism objects, it can be stated that the performance of most of the tourism objects in Mangunan Village is good enough and still needs to be improved. To improve the performance, there is a need to conduct guidance, supervision, and training. The tourism objects need to conduct several things such as improving the security, improving the quality of the creative and innovative selfie spots, adding interesting and creative selfie spots, providing fruit stalls and souvenirs, organizing fruit treatment system, empowering the society to do photography business, conducting customer service training and Occupational Health and Safety training, and many more.

By conducting those strategies, it is expected that the performance of the tourism development will improve and eventually will improve the welfare of the society. Based on the result of the need assessment, each industry needs to follow up the result in the form of research and community service. If the need assessment is fulfilled, the work capacity of each industry will improve and eventually will improve the income of the industries in Mangunan Village.

\section{REFERENCES}

1. Andika, G Very. 2015. Skripsi: "Strategi Pengembangan Obyek Wisata Umbul Ponggok sebagai Daya Tarik Wisata di Desa Ponggol Kecamatan Polanharjo Kabupaten Klaten Jawa Tengah" (Development Strategies for Umbul Ponggok Tourism Object as Tourism Attraction in Ponggok Village, Polanharjo District, Klaten, Central Java)

2. Kussujaniatun, S, "Tourism Potential Mapping Using Ethnographic Approach: A Case Study of Local Tourism Industry," International Conference Social Science And Technology Engineering, 2016. Rencana Pembangunan Jangka Menengah Daerah (RPJMD) Kabupaten Bojonegoro Tahun 2011-2018.

3. Risteski M., Kosevski, J., \&Arnaudov, K. (2012). Spatial Planning and Sustainable Tourism as Basic for Developing Competitive Tourist Destinations. Procedia - Social and Behavioral Sciences, 44, 375-386.

4. Sesotyaningtyas, Mega \&Manaf, Asnawi.(2015). Analysis of Sustainable Tourism Village Development at Kutoharjo Village, Kendal Regency of Central Java. Procedia - Social and Behavioral Sciences, 184, 273-280.

5. Vitasurya, Vicentia Reni. (2015). Local Wisdom for Sustainable Development of Rural Tourism, Case on Kalibiru and Lopati Village, Province of Daerah Istimewa Yogyakarta. Procedia - Social and Behavioral Sciences, 216, 97-108.

6. Wirajaya, Asep Yudha. 2016. Pengembangan Pariwisata Budaya di Daerah Jepara. Etnografi, vol. XVI, no. 1, 1-58. (Cultural Tourism Development in Jepara)

7. Zubaidi. Pengembangan Mayarakat: Wacana and Praktik [Developing Community: Discourse and Practice]. Jakarta: Kencana. 2013.

8. Risteki: The development of the sustainable tourism can be seen from the three significant aspects, which are environment, social, and economy aspects (Fennell, 2003; Baker, 2006; Mowforth\& Munt, 2007; Risteski et al., 2012; Sesotyaningsih \& Manaf, 2015).

9. Kussujaniatun, S., Kismantoroadji, T., Negara, H.K.S. 2017. Tourism Potential Mapping using Ethnographic Approach: A Case of Margomulyo, Kabupaten Bojonegoro. Journal of Engineering and Applied Sciences. 12. 21. 5437-5442. 